\title{
Comparative Accounting - Is It Still Relevant in Today's Global Era of Convergence?
}

\author{
Wan Fuziraihan Wan Abdul Rahim, Shahrul Zariah Mastuki, \\ Yusni Nawi and Ervina Alfan ${ }^{1}$
}

\begin{abstract}
This essay discusses the relevance of comparative accounting in the midst of convergence efforts championed by the international accounting standard setter - the International Accounting Standards Board (IASB). Obstacles to comparability in reference to respective countries' various attributes, namely the regulatory regime and capital market are discussed. In addition, other specific factors such as business and financial environments as well as accounting and auditing culture are also discussed. The essay concludes that although the process of convergence is swiftly taking place worldwide, comparative accounting still remains an important topic to address within all international accounting subjects.
\end{abstract}

Keywords: Comparative, IFRS, Convergence

\section{Introduction}

Accounting information has long been used by decision makers for the assessment of business decisions. As the wave of globalisation sweeps its way to every corner of the world, cross-border integration of markets and politics have consequentially become more intense than before. This has given rise to multiple complexities in business transactions, as well as the business environment. As a result, financial reporting is becoming more and more complex than what is used to be in previous decades.

Given the complexities of the business market place today, it is imperative for the accounting information users, such as the investors, to make the best decisions. Such actions require the use of financial reports. The financial statements contained in companies' annual reports enable investors to make appropriate comparisons with other firms. Hence, it is vital for financial information to possess comparability characteristics. Acknowledging the

1 Corresponding author: Dr Ervina Alfan is a Lecturer at the Faculty of Business and Accountancy, University of Malaya, email: ervina alfan@um.edu.my. 
need for comparability in financial information, the International Accounting Standards Board (IASB) has taken immense steps towards convergence ${ }^{2}$ through the development of the International Financial Reporting Standards (IFRS) for cross-border financial reporting. Thus far, the convergence effort has been largely demonstrated as follows: In Europe the effort was undertaken as early as 2005, when all listed companies from within the European Union (EU) were required to comply with IFRS for the preparation of their consolidated financial statements. Meanwhile, closer to home; in Korea, the use of IFRS for all listed companies was promulgated in 2011; whilst in our very own country of Malaysia, IFRS were effectively implemented on 1 January 2012. Recognising the huge impact of convergence in today's world raises the following question:

"Since IFRS convergence is widespread, is there still a need for comparative accounting?"

This essay discusses the answer to the question above. The essay is structured as follows: Section 2 provides a further discussion on the comparability characteristic. This is followed by Section 3, which discusses comparative accounting and its relevance. Section 4 summarises and concludes the essay.

\section{Comparability}

In accordance with the conceptual framework developed by the IASB, the notion of comparability is defined as the circumstances when financial information is comparable. Accordingly, financial information is comparable if it provides similar information regarding an entity that operates in the same period as well as any other entities. Most importantly, the comparability characteristic allows users of accounting information to identify and understand the similarities and differences contained in the financial information. Understanding the similarities and differences is vital, as it assists the financial users in making investment decisions.

With the advent of the convergence process that is taking place around the globe, IASB hopes that the differences of financial reporting between countries can be further reduced, and thus, provide better financial information to the users with improved comparability. Nevertheless, whilst the intention expressed by the IASB is noble; the fact that each country's politics, socio-economics and history, as well as regulatory regimes are relatively unique, places the convergence process on questionable grounds. This is further discussed in the following section.

\footnotetext{
$2 \quad$ Ball (2006) defines convergence as the process of reducing the differences between IFRS and the national accounting standards of various countries.
} 


\section{Comparative Accounting and Its Relevance}

Resultant from the rich and diverse historical background of every country in the world, the political and economic settings for each country therefore, exhibit heterogeneity rather than a single homogeneous landscape. Accordingly, the degree of capitalism in each country varies, with some countries appearing to have capital markets that dominate the financial system; whilst for others, the existence of non-market coordinating institutions (such as industrial trade bodies and inter-firms' joint efforts in providing training and education to the workforce) are more fundamental to a certain extent in contributing towards the country's economic development. Hence, users of financial information need to understand these countries' respective differences before financial decisions are made. This aspect is widely known as comparative accounting.

In addition to the degree of the capitalism factor, other important determinants that shape a country's economic settings generally include the financial reporting quality $^{3}$; and specifically, the regulatory regime and its institutional framework. It is found that the code law countries (France, Germany and Japan) provide less timely accounting information in comparison to the common law countries such as Australia, Canada, the U.K., the U.S. and New Zealand. This finding supports the presumption that the code law countries have greater concern for other stakeholders in the firm, including the governments and employees, in addition to the shareholders. As a result, the regulators in these countries have less authority than its common law counterparts to impose requirements on companies with regard to financial information. On the other hand, the common law countries are predominantly influenced by concerns of the shareholders. This is demonstrated by the support in the countries' institutional agencies, apart from the regulatory regime (eg: security regulation), in enforcing the shareholders' rights. In addition to these factors, other factors that play equal role in shaping the economic settings in each country include business and financial culture, as well as the accounting and auditing culture.

Under the business and financial culture, it is important to note that each country has a unique business environment that results in distinctive business operations in the respective country's context. For instance, Anglo American countries like the US, the UK and Canada's individual equity capital markets have been dominating each country's main source of financing for many years. Hence, companies in these countries are required by the regulators to present extensive and truthful financial disclosures for their investors and shareholders' evaluation of companies' performance. In contrast, although the condition has been gradually changing since the mid-1990s, many countries on the European

\footnotetext{
The quality of financial reporting differs amongst countries. Financial reporting is said to be of a high quality if it provides reliable, meaningful, relevant as well as accurate information to the financial users. A country with high quality financial reporting is able to attract foreign investors, whilst financial statements in a regime with a relatively lower financial reporting quality do not earn the similar extent of trust within the investors' community.
} 
continent, as well as other parts of the world, rely on the banks, the state and family as sources of financing; rather than the capital market. As a result, due to the close ownership of business equity, their financial reporting was not designed to disclose extensive information to the public.

For the accounting and auditing culture, it is useful to first define the term. The term accounting and auditing culture is defined as the accounting and auditing habitual practice in each respective country, as a result of its business and financial environment. The environment of the business and financial context shapes the "accepted" practice or norm, and the mentality of both the accountants and the auditors. In regard to this, the accountants' and auditors' approach in preparing and auditing the financial statements varies, depending on the business and the financial environment. For example, Germany is one of the countries that aim to minimise the income tax burden of companies by providing tax incentives. Asset impairment losses are tax deductible in Germany, but not in the U.K. Hence, German accountants might be more motivated to show a loss in their accounts in order to get tax deductions; although their decision in this manner might not be agreed with by their U.K. counterparts. The mindsets of the auditors are no different in this respect. In some countries, the auditors give qualifications to companies that fail to follow national standards or IAS; whereby the failure of disclosure could lead to material results. On the other hand, such a mindset is not similarly adopted by auditors in countries where the auditors' qualification of financial statements are regarded as a sensitive case. Thus, auditors' qualifications in this respect are treated with extreme precaution as they can lead to increased anxiety amongst the business community.

In short, these factors, namely degree of capitalism, regulatory regime and institutional framework, business and financial culture as well as accounting and auditing culture demonstrate that although the convergence process is actively occurring around the globe, a deep understanding of each respective country's historical, political, economic and regulatory settings are indeed important to obtain a better understanding of its financial statements.

\section{Summary and Conclusion}

To conclude, convergence is a global phenomenon that has occurred in this decade and will continue into the future. Although the merits of convergence are acknowledged in the sense that it seeks to improve comparability of financial statements amongst countries, it is imperative that the users are aware of each respective country's political and economic setting, alongside its regulatory regime and business and financial culture, as well as their accounting and auditing culture. This will ensure that the financial information is not only 'comparable,' but comparable in a more 'genuine' way. In this respect, to answer the question put forth in the previous section, it is essential that the comparative accounting topic continues to be emphasised and taught in international accounting classes; 
despite the rapid advancement of the convergence process that is taking place around the globe.

\section{References}

AICPA. What is IASB?. IFRS Resources, from http://www.ifrs.com/ifrs faqs. html.

Ball, R. (2006). International Financial Reporting Standards (IFRS): pros and cons for investors. Accounting and Business Research, 36(1): 5-27.

Ball, R., S. P. Kothari, et al. (2000). The effect of international institutional factors on properties of accounting earnings. Journal of Accounting and Economics , 29(1): 1-51.

Chin, S. S.-F. and J. A. Hortin (1993). A survey on the perceptions of elementary teacher's use of technology and the implications for inservice. International Journal of Instructional Media, 20 (4): 317-332.

Doupnik, T. and H. Perera (2012). International Accounting. New York, McGrawHill.

IASB. The IFRS Framework, from http://www.iasplus.com/en/standards/ framework.

Smith, L. M. (2011). Key Differences between IFRS and U.S. GAAP: Impact on Financial Reporting; A FAR Grant Research Summary, The Association for Accountants and Financial Professionals in Business.

Tsakumis, G. T., D. R. Campbell, Sr, et al. (2009). IFRS: Beyond the Standards. Journal of Accountancy 207(2): 34-39.

Walker, M. (2010). Accounting for varieties of capitalism: The case against a single set of global accounting standards. British Accounting Review. 42(3): 137-152.

Zeff, S. A. (2007). Some obstacles to global financial reporting comparability and convergence at a high level of quality. British Accounting Review. 39(4): 290-302.

Zhang, Y. and J. Andrew (2010). Land in China: Re-considering comparability in financial reporting. Australasian Accounting Business and Finance Journal , 4(1): 53-75.

\section{Notes}

At the time of writing, the authors (Wan Fuziraihan Wan Abdul Rahim, Shahrul Zariah Mastuki and Yusni Nawi) were MBA students at the Faculty of Business and Accountancy, at the University of Malaya. The article has been adapted, re-produced and re-written based on the students' assignment for the "Issues in International Accounting" course. 